\title{
The Effect of Heat Treatment on the Microstructure and Mechanical Properties of Cu-Al-Mn Shape Memory Alloy
}

\author{
S. Kožuh, ${ }^{a^{*}}$ M. Gojić, a I. Ivanić, ${ }^{a}$ T. Holjevac Grgurić, \\ B. Kosec, ${ }^{\text {b }}$ and I. Anželc \\ a University of Zagreb, Faculty of Metallurgy, Aleja narodnih heroja 3, 44103 Sisak, Croatia \\ b University of Ljubljana, Faculty of Natural Science and Engineering, Aškerčeva 12, \\ 1000, Ljubljana, Slovenia \\ ' University of Maribor, Faculty of Mechanical Engineering, Smetanova 17, 2000, Maribor, Slovenia
}

\begin{abstract}
The 8-mm diameter bars of $\mathrm{Cu}-\mathrm{Al}-\mathrm{Mn}$ shape memory alloys were produced by continuous casting technique. The samples were characterised using optical microscopy and scanning electron microscopy along with EDX analysis. The continuous cast alloy revealed some martensitic phase, which, after quenching, led to the microstructure that is completely martensite. Quenching of samples had an effect on several mechanical properties and change in morphology of fracture. After ageing at $200{ }^{\circ} \mathrm{C}$ and $300^{\circ} \mathrm{C}$, the tensile strength increased and elongation drastically decreased. Morphology of fracture surface changed from primary ductile to a mixture of intergranular and ductile.
\end{abstract}

\section{Keywords}

Shape memory alloys (SMAs), mechanical properties, microstructure, scanning electron microscopy (SEM), quenching, ageing

\section{Introduction}

Shape memory alloys (SMAs) are relatively new metallic materials, which are able to memorise and recover their original shape. These alloys show the ability to return to some previously defined shape or size when subjected to the appropriate treatment. It is a result of crystallographically reversible martensitic phase transformation. Such phase transformations can be obtained by mechanical (loading) or thermal treatment (both cooling and heating). SMAs are extremely sensitive to exact chemical composition, grain size, processing parameters, heat treatment, loading conditions, etc. The main types of these alloys are nitinol (Ni-Ti), Cu-based, and Fe-based alloys. ${ }^{1-3}$

SMAs are interesting in numerous commercial engineering applications. There is a high demand for SMAs with high strength and shape memory effect in technical applications. ${ }^{2}$ The main advantages of $\mathrm{Cu}$-based alloys are their low price, relatively simple fabrication procedure, and high electrical and thermal conductivity compared to other shape memory alloys. Among Cu-based SMAs, the Cu$\mathrm{Al}-\mathrm{Ni}$ and $\mathrm{Cu}-\mathrm{Al}-\mathrm{Zn}$ alloys are extensively investigated. ${ }^{4-6}$ However, the Cu-Al-Ni and Cu-Al-Zn alloys are brittle and susceptible to intergranular fracture. For this reason, the $\mathrm{Cu}-\mathrm{Al}-\mathrm{Mn}$ shape memory alloy is proposed because it was found that the alloy shows better ductility and good strain recovery. The reason for higher ductility of $\mathrm{Cu}-\mathrm{Al}-\mathrm{Mn}$ shape memory alloys can be correlated to decreasing the degree of order of the $\beta$ parent phase. ${ }^{7,8}$ Addition of manganese to Cu-based SMAs stabilises the parent phase and improves ductility of the alloys. ${ }^{9}$ The other advantages of $\mathrm{Cu}$-Al-Mn alloys compared to other Cu-based SMAs are higher shape

*Corresponding author: Assoc. Prof. Stjepan Kožuh, PhD. e-mail: kozuh@simet.hr memory strain, larger recovery power, better ductility, and higher damping capacity. The addition of manganese increases the binding force between the constituent atoms leading to increased activation energy for diffusion and decreased diffusion rate of the atom for re-ordering. ${ }^{10}$

Generally, SMAs are fabricated by the casting procedure followed by plastic working (rolling or drawing) including heat treatment. In recent years, the continuous casting technique has been one of many technologies for the production of SMAs due to the special competitive growth mechanism of crystal, and resulting cast products with a favourable texture formation. ${ }^{11,12}$ In this paper, the mechanical properties of $\mathrm{Cu}-\mathrm{Al}-\mathrm{Mn}$ shape memory alloys obtained through the continuous casting process and after heat treatment (quenching and ageing) were compared.

\section{Experimental}

The Cu-Al-Mn alloy (Table 1) used in this research was prepared by melting pure elements $(w(\mathrm{Cu})=99.9 \%$, $w(\mathrm{Mn})=99.8 \%$, and $w(\mathrm{Al})=99.5 \%$ ) in a vacuum induction furnace under protective argon atmosphere. Chemical composition of the investigated alloy was estimated by Optical Emission Spectrometer ICP-OES AGILENT 700. Firstly, the ingot $(\Phi=110 \mathrm{~mm} \times 180 \mathrm{~mm})$ was produced by graphite mould casting. The ingot was then remelted in the same furnace and continuously cast. The continuously cast strand (cylindrical bar with $8 \mathrm{~mm}$ diameter) of alloy was obtained using the device for vertical continuous casting which is connected to the vacuum induction furnace. Solid bars were produced directly from the $13.15 \mathrm{~kg}$ melt. Starting temperature of the melt was $1250{ }^{\circ} \mathrm{C}$. The process of remelting was performed in vacuum (2-4) $\cdot 10^{-1}$ mbar. During casting, pressure of argon 
protective atmosphere was set around 500 mbar. Casting speed was $290 \mathrm{~mm} \mathrm{~min}^{-1}$. Heat treatment of samples was performed in a laboratory electro-resistance furnace. Solution annealing of samples was carried out at $900{ }^{\circ} \mathrm{C}$ for $30 \mathrm{~min}$, followed by cooling in room-temperature water (quenching). After quenching, the ageing was carried out at temperatures of $100{ }^{\circ} \mathrm{C}, 200{ }^{\circ} \mathrm{C}$, and $300{ }^{\circ} \mathrm{C}$ for $60 \mathrm{~min}$, followed by cooling in water.

Table 1 - Chemical composition of Cu-Al-Mn alloy Tablica 1 - Kemijski sastav Cu-Al-Mn legure

\begin{tabular}{c|c|c}
\hline$w(\mathrm{Cu}) / \%$ & $w(\mathrm{Al}) / \%$ & $w(\mathrm{Mn}) / \%$ \\
\hline 82.3 & 8.3 & 9.4 \\
\hline
\end{tabular}

Mechanical properties of samples were determined by tensile testing Zwick machine $50 \mathrm{kN}$ at stretching rate of $3 \mathrm{~mm} \mathrm{~min}{ }^{-1}$. Hardness was tested by Vickers method (HV10). The specimen microstructure was characterised by optical microscopy $(\mathrm{OM})$ and scanning electron microscopy (SEM) equipped with energy dispersive spectroscopy (EDX). For OM and SEM analysis, the samples were ground (from 120 to 1000 grade paper), and polished $(0.3 \mu \mathrm{m}$ $\mathrm{Al}_{2} \mathrm{O}_{3}$ ). Further, the samples were etched in a solution composed of $2.5 \mathrm{~g} \mathrm{FeCl}_{3}$ and $48 \mathrm{ml}$ methanol in $10 \mathrm{ml} \mathrm{HCl}$. After tensile testing, the fracture morphologies of alloys were determined again using SEM equipped with EDX.

\section{Results and discussion}

\subsection{Microstructure investigation}

Figs. 1-4 show OM and SEM micrographs of the Cu-Al-Mn alloy after continuous casting and heat treatment. Grain boundaries are clearly identified by OM (Fig. 1). The grain size of alloy after quenching (Fig. 1b) is much higher compared to those of continuous cast alloy (Fig. 1a). After continuous casting, some martensite phase is observed (Figs. 1a and 3a). At the betatization temperature of $900{ }^{\circ} \mathrm{C}$, the $\mathrm{Cu}$ Al-Mn alloy has $\beta$ phase with a disordered bcc structure. After solution annealing at $900{ }^{\circ} \mathrm{C}$ and quenching in water, the samples at room temperature contain $\beta_{1}{ }^{\prime}$ martensite and $\beta$ parent phase, as may be seen in Figs. $1 \mathrm{~b}$ and $3 \mathrm{~b}$. By rapid cooling in water, the alloy undergoes ordering transitions $\beta(\mathrm{A} 2) \rightarrow \beta 2(\mathrm{~B} 2) \rightarrow \beta 1\left(\mathrm{~L} 2_{1}\right)$, and then martensite transformation $\beta_{1}\left(\mathrm{~L} 2_{1}\right) \rightarrow \beta_{1}{ }^{\prime}$ occurs. ${ }^{13}$ During rapid cooling from the stable $\beta$-phase region the martensitic phase occurs below the $M_{s}$-temperature. The micrographs include grains and martensite plates (Figs. 1-3). The grains appear clearly, and martensite plates have different orientations into different grains. The martensite is formed primarily as the needle-like shape. In some fields, the V-shape martensite was noticed. This is typical self-accommodating zig-zag martensite morphology, which is characteristic for the $\beta^{\prime}$ martensite in SMAs. The parallel bands in martensite can be considered twin-like martensite. As a typical example, Fig. 1 and Table 2 show the EDX results of Cu-Al-Mn alloy after quenching and aging at $300{ }^{\circ} \mathrm{C}$.
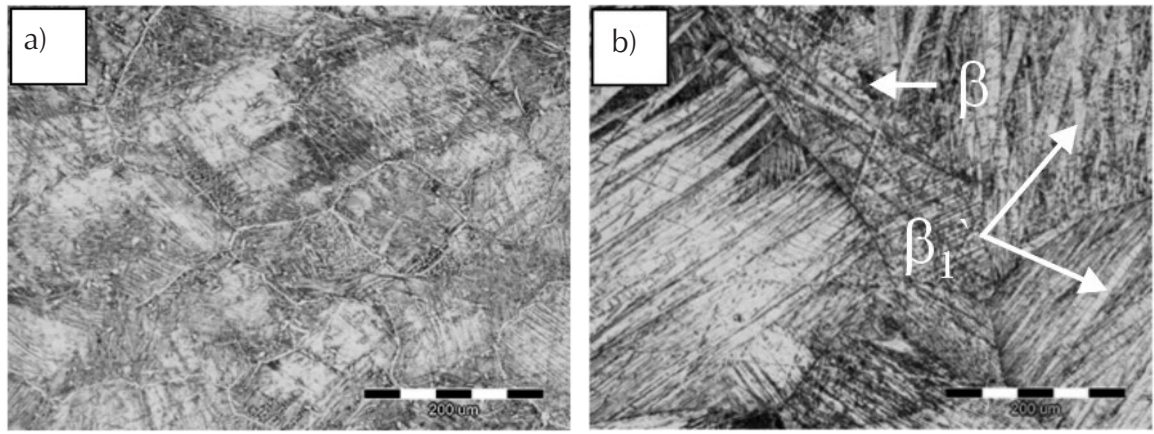

Fig. 1 - OM micrographs of the Cu-Al-Mn alloy after continuous casting (a) and after quenching (b)

Slika 1 - OM mikrografije Cu-Al-Mn legure nakon kontinuiranog lijevanja (a) i nakon kaljenja (b)
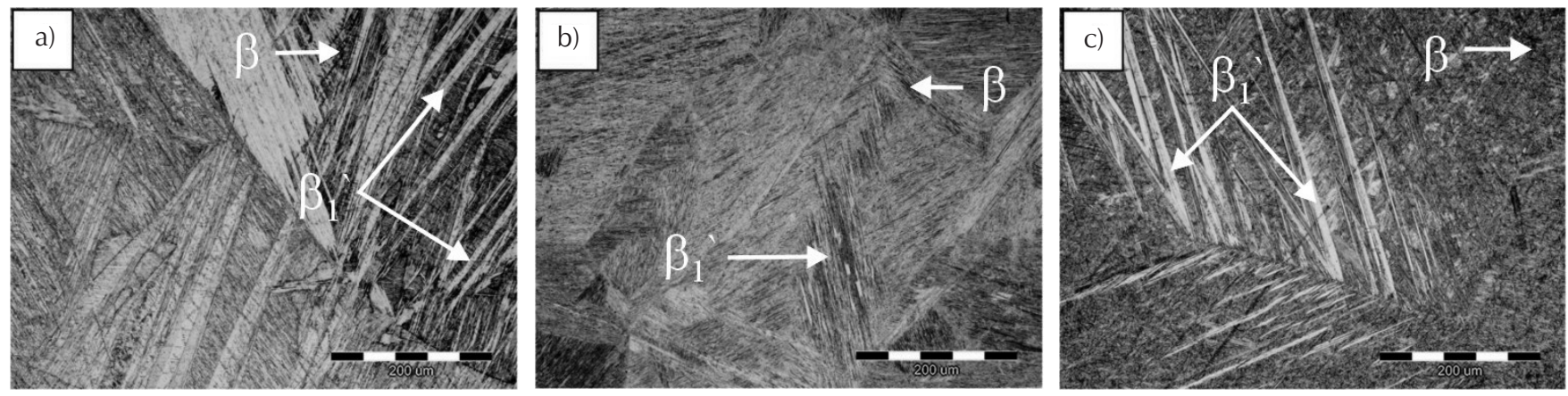

Fig. 2 - OM micrographs of the Cu-Al-Mn alloy after ageing at $100{ }^{\circ} \mathrm{C} / 60 \mathrm{~min} / \mathrm{H}_{2} \mathrm{O}(\mathrm{a}), 200{ }^{\circ} \mathrm{C} / 60 \mathrm{~min} / \mathrm{H}_{2} \mathrm{O}(\mathrm{b})$ and $300{ }^{\circ} \mathrm{C} / 60 \mathrm{~min} / \mathrm{H}_{2} \mathrm{O}(\mathrm{c})$ Slika 2 - OM mikrografije Cu-Al-Mn legure nakon starenja pri $100{ }^{\circ} \mathrm{C} / 60 \mathrm{~min} / \mathrm{H}_{2} \mathrm{O}$ (a), $200{ }^{\circ} \mathrm{C} / 60 \mathrm{~min} / \mathrm{H}_{2} \mathrm{O}$ (b) i $300{ }^{\circ} \mathrm{C} / 60 \mathrm{~min} / \mathrm{H}_{2} \mathrm{O}$ (c) 

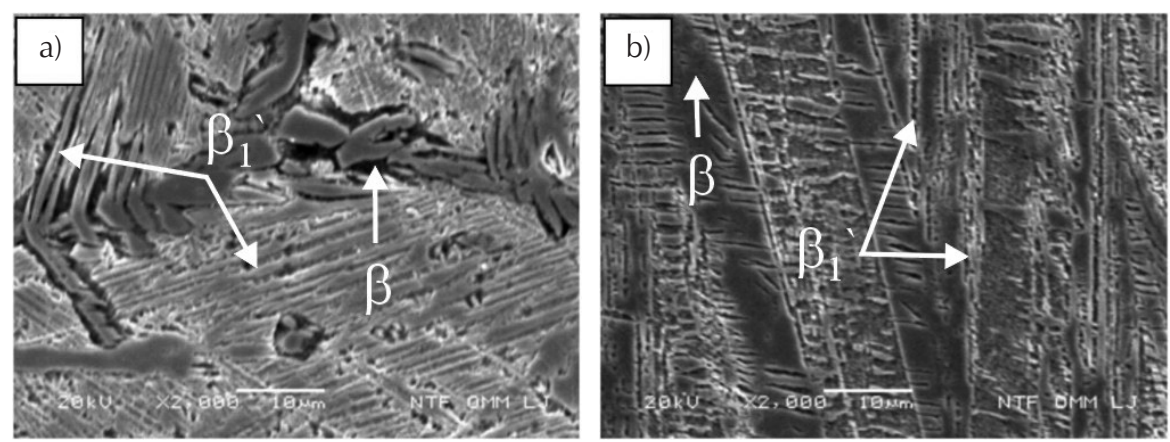

Fig. 3 - SEM micrographs of the Cu-Al-Mn alloy after continuous casting (a) and after quenching (b)

Slika 3 - SEM mikrografije Cu-Al-Mn legure nakon kontinuiranog lijevanja (a) i kaljenja (b)
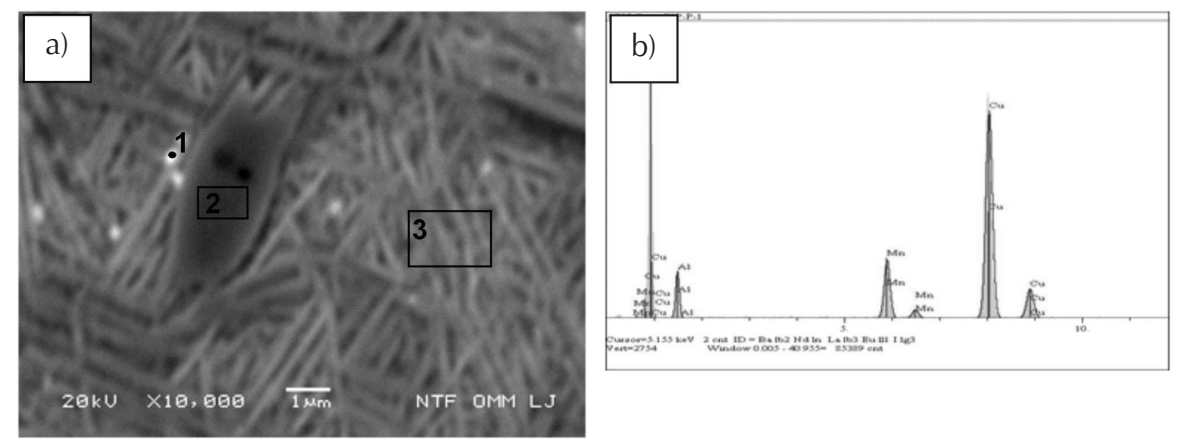

Fig. 4 - SEM micrographs of the Cu-Al-Mn alloy after quenching and ageing at $300{ }^{\circ} \mathrm{C}$ (a) with EDX spectrum of position 2 (b)

Slika 4 - SEM mikrografije Cu-Al-Mn legure nakon kaljenja i starenja pri $300{ }^{\circ} \mathrm{C}$ (a) s EDX spektrom pozicije 2 (b)

Table 2 - Chemical composition of positions marked in Fig. 4a

Tablica 2 - Kemijski sastav pozicija označenih na slici 4a

\begin{tabular}{l|c|c|c}
\hline Position & $w(\mathrm{Cu})$ & $w(\mathrm{Al})$ & $w(\mathrm{Mn})$ \\
\hline position 1 & 83.25 & 7.88 & 8.87 \\
position 2 & 85.46 & 5.77 & 8.77 \\
position 3 & 84.57 & 6.39 & 9.04 \\
\hline
\end{tabular}

SEM fracture surface of the Cu-Al-Mn alloy after continuous casting, quenching and aging at $300{ }^{\circ} \mathrm{C}$ are presented in Figs. 5-7. Results of EDX analysis of fracture surface after quenching and aging at $300{ }^{\circ} \mathrm{C}$ are given in Fig. 8 and Table 3.
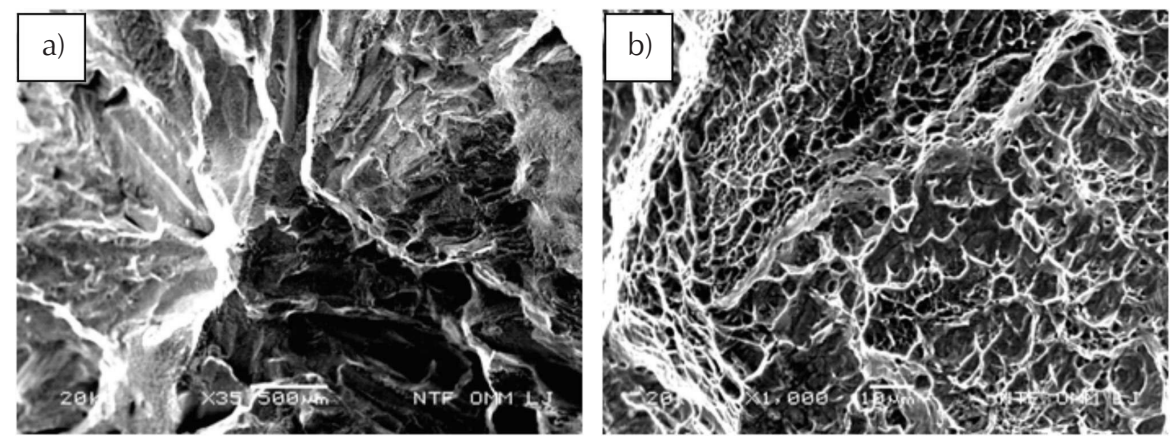

Fig. 5 - SEM fracture surfaces of the Cu-Al-Mn alloy after continuous casting at different magnifications

Slika 5 - SEM prijelomne površine Cu-AI-Mn legure nakon kontinuiranog lijevanja pri različitim povećanjima 

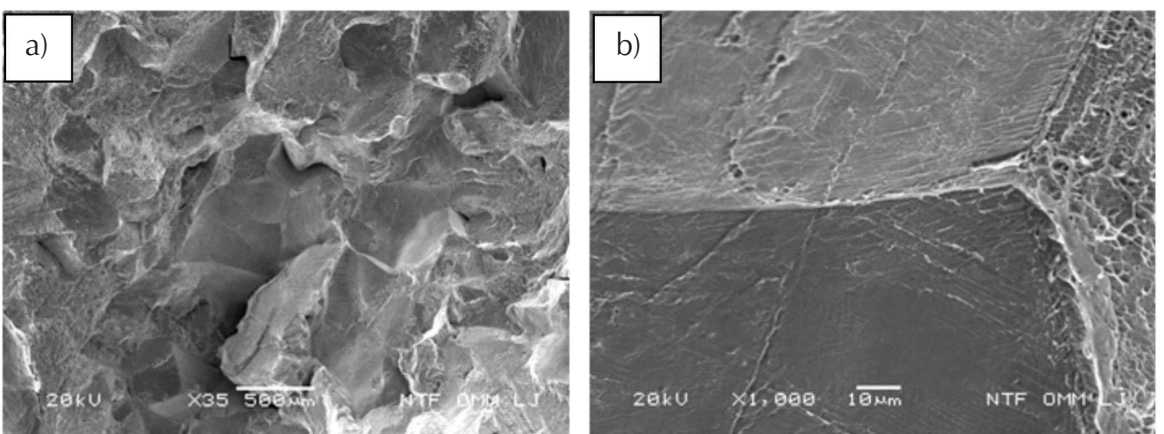

Fig. 6 - SEM fracture surfaces of the Cu-AI-Mn alloy after quenching (at $900{ }^{\circ} \mathrm{C} / 30 \mathrm{~min} /$ $\left.\mathrm{H}_{2} \mathrm{O}\right)$ at different magnifications $(\mathrm{a}-35 \times, \mathrm{b}-1000 \times)$

Slika 6 - SEM prijelomne površine Cu-Al-Mn legure nakon kaljenja $\left(900{ }^{\circ} \mathrm{C} / 30 \mathrm{~min} / \mathrm{H}_{2} \mathrm{O}\right)$ pri različitim povećanjima $(a-35 \times, b-1000 \times)$
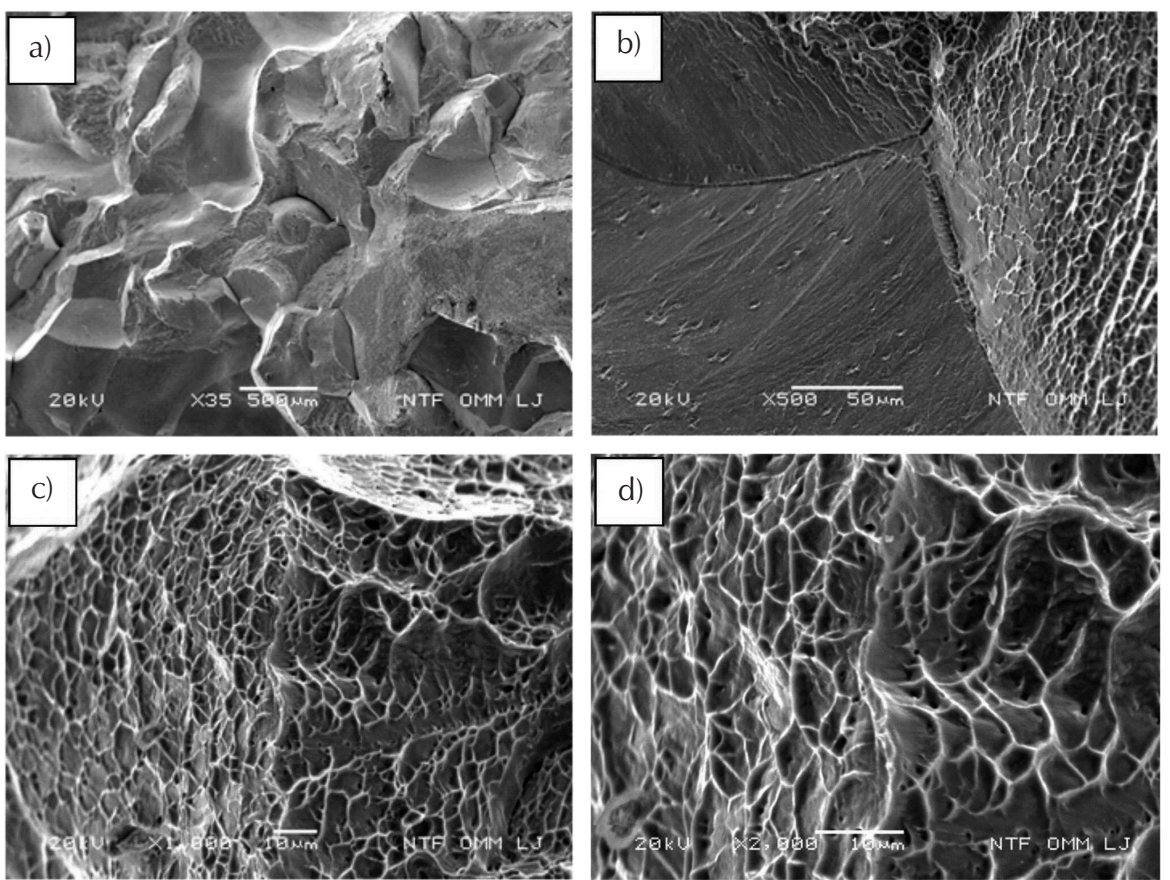

Fig. 7 - SEM fracture surfaces of the Cu-Al-Mn alloy after quenching (at $900{ }^{\circ} \mathrm{C} / 30 \mathrm{~min} /$ $\mathrm{H}_{2} \mathrm{O}$ ) and ageing at $300{ }^{\circ} \mathrm{C}$, at different magnifications

Slika 7 - SEM prijelomne površine Cu-Al-Mn legure nakon kaljenja $\left(900{ }^{\circ} \mathrm{C} / 30 \mathrm{~min} / \mathrm{H}_{2} \mathrm{O}\right)$ i starenja pri $300^{\circ} \mathrm{C}$, kod različitih povećanja
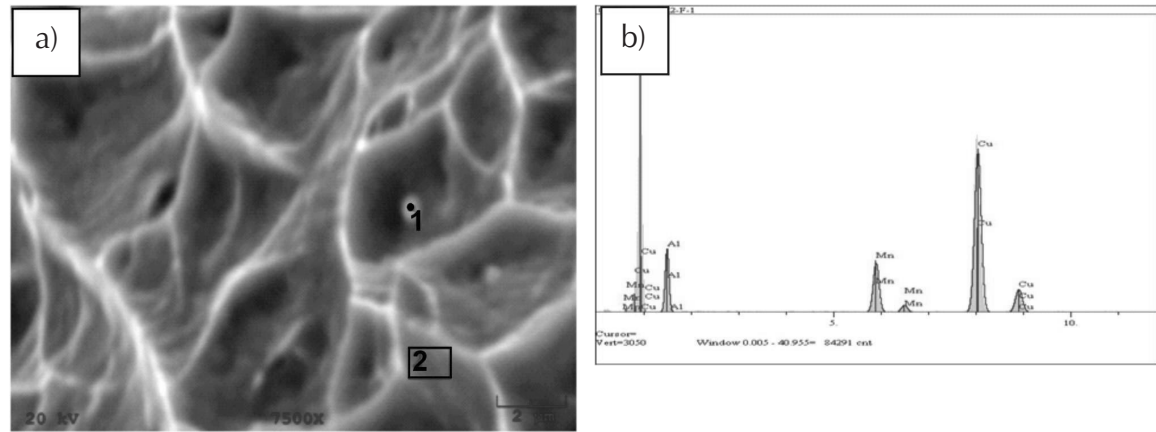

Fig. 8 - SEM fracture surfaces of the Cu-Al-Mn alloy after quenching (at $900{ }^{\circ} \mathrm{C} / 30 \mathrm{~min} /$ $\mathrm{H}_{2} \mathrm{O}$ ) and ageing at $300{ }^{\circ} \mathrm{C}$ (a) and EDX spectrum of position 1 (b)

Slika 8 - SEM prijelomne površine Cu-Al-Mn legure nakon kaljenja $\left(900{ }^{\circ} \mathrm{C} / 30 \mathrm{~min} / \mathrm{H}_{2} \mathrm{O}\right)$ i starenja pri $300^{\circ} \mathrm{C}$ (a) i EDX spektar pozicije 1 (b) 
Table 3 - Chemical composition of positions marked in Fig. 8a Tablica 3 - Kemijski sastav pozicija označenih na slici 8a

\begin{tabular}{l|c|c|c}
\hline Position & $w(\mathrm{Cu})$ & $w(\mathrm{Al})$ & $w(\mathrm{Mn})$ \\
\hline position 1 & 81.42 & 9.32 & 9.26 \\
position 2 & 84.97 & 5.51 & 9.52 \\
\hline
\end{tabular}

\subsection{Mechanical properties determination}

The effect of heat treatment on mechanical properties of $\mathrm{Cu}-\mathrm{Al}-\mathrm{Mn}$ shape memory alloy was determined performing the standard tensile tests. Table 4 shows measured mechanical properties of the alloy. The values presented are average values obtained after four measurements. Results of mechanical properties presented in Table 4 show that tensile strength and elongation of the alloy are significantly affected by heat treatment. After continuous casting, the $\mathrm{Cu}-\mathrm{Al}-\mathrm{Mn}$ alloy shows tensile strength of $627 \mathrm{MPa}$, elongation of $8.5 \%$, and reduction in area of $17.9 \%$. The values of mechanical properties in as-cast state are in accordance with Mielczarek et al. ${ }^{14}$ which investigated mechanical properties of Cu-Al-Mn SMA with different chemical compositions $(w(\mathrm{Al})=8.9-12.5 \%$ and $w(\mathrm{Mn})=3.3-9.3 \%)$. It is clear that the tensile strength, elongation, and reduction in area of the alloy decrease in quenched state. After ageing at $100{ }^{\circ} \mathrm{C}$, all measured mechanical properties increase in comparison with quenched state. The enhanced ductility (elongation and reduction in area) of the alloy can result in improved workability of the alloy, and thus can be useful for practical application. Tensile strengths of the alloy are higher for 60-130 MPa than those obtained for the same alloy in research Sotou et al. ${ }^{15}$ By ageing at $200{ }^{\circ} \mathrm{C}$ and $300{ }^{\circ} \mathrm{C}$, the tensile strength is significantly increased, while the plasticity of the alloy is very low (below $2 \%$ ). The highest tensile strength is obtained after aging at $300{ }^{\circ} \mathrm{C}$ (1002 MPa). This value is about $300 \mathrm{MPa}$ higher compared to the alloy after continuous casting.

Table 4 - Mechanical properties of Cu-Al-Mn alloy

Tablica 4 - Mehanička svojstva Cu-Al-Mn legure

\begin{tabular}{l|c|c|c}
\hline State & $\begin{array}{c}\text { Tensile } \\
\text { strength } / \mathrm{MPa}\end{array}$ & Elongation /\% & $\begin{array}{c}\text { Reduction } \\
\text { in area } / \%\end{array}$ \\
\hline as-cast & 627 & 8.5 & 17.9 \\
quenched & 555 & 7.6 & 7.5 \\
ageing at $100{ }^{\circ} \mathrm{C}$ & 688 & 10.2 & 12.2 \\
ageing at $200{ }^{\circ} \mathrm{C}$ & 951 & 1.4 & 1.6 \\
ageing at $300{ }^{\circ} \mathrm{C}$ & 1002 & 1.7 & 1.7 \\
\hline
\end{tabular}

The changes in mechanical properties (Table 4), especially the decrease in elongation and reduction in area of the alloy, can be caused by the change in microstructure or metastable character of the $\beta_{1}$ phase and precipitation process in Cu-based shape memory alloys. ${ }^{16}$ Microstructural change of cast, quenched, and aged samples can be explained by analysis of SEM micrographs with EDX spec- trums and fracture surfaces (Figs. 4-8). Optical micrographs of samples after ageing show no microstructural changes that can have an influence on mechanical properties, but on the SEM micrographs these changes can be observed (Figs. 2 and 4). After ageing, a very fine dispersion of second $\mathrm{Cu}$-rich phase particles is precipitated in the $\beta_{1}$ matrix (Fig. 4). Ageing at $300{ }^{\circ} \mathrm{C}$ is accompanied by the precipitation of these phase particles and causes a chemical composition change in the matrix. EDX analysis of particles shows higher Cu-content and lower Al-content compared to the matrix (Fig. 4, Table 2).

The hardness of the alloy increased as the result of dispersion hardening, Fig. 9. Ageing in martensite phase is associated with diffusion and precipitation process. With the increase in ageing temperature, the increase in hardness corresponds to the precipitation of the particles. Obviously, the ageing is a problem for Cu-based shape memory alloys. Sutou et al. concluded that the increase in hardness by low temperature treating from 200 to $400{ }^{\circ} \mathrm{C}$ of $\mathrm{Cu}-\mathrm{Al}-$ Mn SMAs is due to the formation of fine microstructure with plate-like bainite plates and the increase in the degree of order in the parent $\beta_{1}$ phase. ${ }^{17}$ Kainuma suggests that the corresponding stable phases in $\mathrm{Cu}-\mathrm{Al}-\mathrm{Mn}$ alloys in the low-temperature range below $400{ }^{\circ} \mathrm{C}$ can be $\mathrm{Cu}_{3} \mathrm{Mn}_{2} \mathrm{Al}$ phase. ${ }^{18}$ The metastable martensite and parent phase from $\beta$ phase quenching can be stabilised easily by the time-dependent diffusion process during aging. ${ }^{19}$ According to the results of Stanciu et al. for Cu-Al-Mn alloy with mass fraction of $\mathrm{Al}$ higher than $20 \%$, the $\mathrm{Cu}_{3} \mathrm{Al}$ phase could be formed. ${ }^{20}$

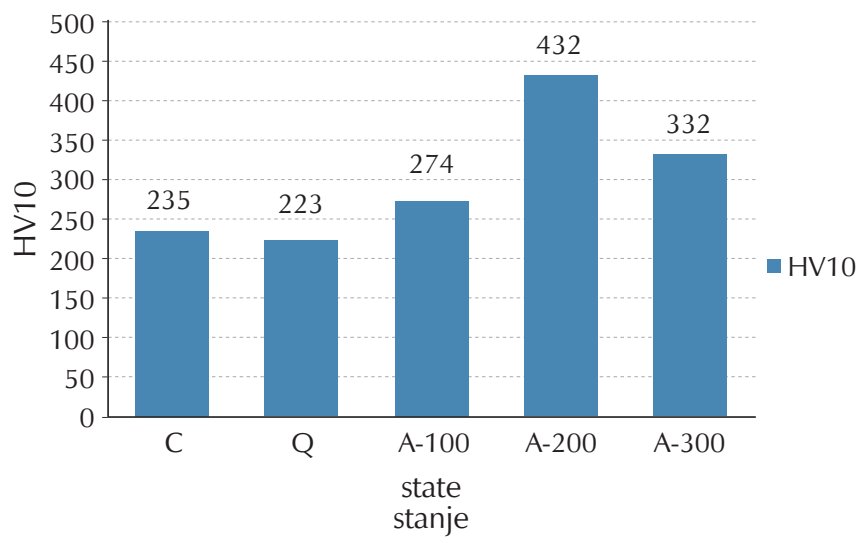

Fig. 9 - Hardness values of different states of investigated $\mathrm{Cu}$ Al-Mn SMA (C - cast; Q - quenched at $900^{\circ} \mathrm{C} / 30 \mathrm{~min} /$ $\mathrm{H}_{2} \mathrm{O}$; A-100 - ageing at $100{ }^{\circ} \mathrm{C} / 60 \mathrm{~min} / \mathrm{H}_{2} \mathrm{O} ; \mathrm{A}-200$ - ageing at $200{ }^{\circ} \mathrm{C} / 60 \mathrm{~min} / \mathrm{H}_{2} \mathrm{O} ; \mathrm{A}-300$ - ageing at $300{ }^{\circ} \mathrm{C} / 60 \mathrm{~min} / \mathrm{H}_{2} \mathrm{O}$ )

Slika 9 - Vrijednosti tvrdoće različitih stanja istraživane $\mathrm{Cu}-\mathrm{Al}-\mathrm{Mn}$ SMA (C - lijevano; Q - kaljeno $900{ }^{\circ} \mathrm{C} / 30 \mathrm{~min} / \mathrm{H}_{2} \mathrm{O}$; A-100 - stareno $100{ }^{\circ} \mathrm{C} / 60 \mathrm{~min} / \mathrm{H}_{2} \mathrm{O} ; \mathrm{A}-200$ - stareno $200{ }^{\circ} \mathrm{C} / 60 \mathrm{~min} / \mathrm{H}_{2} \mathrm{O} ; \mathrm{A}-300$ - stareno $300{ }^{\circ} \mathrm{C} / 60 \mathrm{~min} /$ $\left.\mathrm{H}_{2} \mathrm{O}\right)$

It is evident from Table 2 that elongation and reduction in area is decreased by quenching. The previous statement is confirmed by Figs. 5-8 showing SEM fracture surfaces of samples after tensile testing. Microfractographs show 
that the fracture of alloy changes significantly by heat treatment. In the cast condition, fracture surfaces are primary ductile (Fig. 5), while after quenching, as well as after ageing, fracture surfaces are a mixture of intergranular and ductile fracture (Figs. 6 and 7). In some cases, it can be noticed that the crack occurs at three-fold node of grain boundaries (Figs. $6 \mathrm{~b}$ and $7 \mathrm{~b}$ ). Brittle grain boundary cracking in Cu-based shape memory alloys was caused due to a high degree of order, high elastic anisotropy, and large grain size. ${ }^{21}$ Grain boundaries often provide the easiest propagation path. In addition, not only intergranular type of fracture was noticed in this sample. Some places at fracture surface show characteristically small and shallow dimples, possibly indicating that a certain plastic deformation occurred during the fracture. The fracture surface was also investigated with an EDX analysis. Fig. 8a shows a fracture surface of specimen after aging at $300{ }^{\circ} \mathrm{C}$ with dimples, in which the existence of small particles was observed. EDX analysis showed that the chemical composition of observed particle has higher $\mathrm{Al}$-content in comparison to the matrix (Fig. 8, Table 3).

The results of hardness measurements are presented in Fig. 9. Hardness in cast and quenched state gives similar values (235 HV10 and 223 HV10). In ageing condition, the value of hardness in all samples increases. After ageing at $100{ }^{\circ} \mathrm{C}$, hardness was $274 \mathrm{HV} 10$, while after ageing at $200{ }^{\circ} \mathrm{C}$ and $300{ }^{\circ} \mathrm{C}$, hardness values significantly increase (432 HV10 and 332 HV10). Increase in hardness values can be caused by the second phase particle presence.

\section{Conclusions}

Continuous casting is revealed as a useful technique for production of Cu-Al-Mn SMAs bars (in our case with diameter of $8 \mathrm{~mm}$ ). After continuous casting, the alloy shows tensile strength of $627 \mathrm{MPa}$ and elongation of $8.5 \%$. Microstructure consists primarily of martensite $\left(\beta^{\prime}\right)$, and parent phase ( $\beta$-phase).

After quenching the alloys microstructure completely becomes martensite, and mechanical properties are decreased in comparison to the cast state (tensile strength of $555 \mathrm{MPa}$ and elongation of $7.6 \%$ ). By increasing the ageing temperature from $100{ }^{\circ} \mathrm{C}$ to $200{ }^{\circ} \mathrm{C}$, and $300{ }^{\circ} \mathrm{C}$, the tensile strength significantly increased, while the plasticity of the alloy was very low (below $2 \%$ ). These changes in mechanical properties can be due to change in grain size and microstructure. In addition, the morphology of fracture surface changed from primary ductile to a mixture of intergranular and ductile fracture types.

\section{ACKNOWLEDGEMENTS}

This work has been fully supported by Croatian Science Foundation under the project (IP-2014-09-3405).

\section{List of abbreviations and symbols Popis kratica i simbola}
SMAs - shape memory alloys
- legure s prisjetljivosti oblika
SEM - scanning electron microscopy
- pretražna elektronska spektroskopija
OM - optical microscopy
- optička mikroskopija
EDX - energy dispersive spectroscopy
- energijski disperzivna spektroskopija

\section{References \\ Literatura}

1. C. Lexcellent, Shape-memory Alloys Handbook, John Wiley\&Sons, New York, 2013, doi: https://doi. org/10.1002/9781118577776.

2. J. M. Jani, M. Leary, A. Subic, M. A., Gibson, A review of shape memory alloy research, applications and opportunities, Mater. Design 56 (2014) 1078-1113, doi: https://doi. org/10.1016/j.matdes.2013.11.084.

3. D. Ćorić, M. Franz, Properties and application of shape memory alloys, Welding (in Croatien) 5-6 (2007) 179-187.

4. G. Lojen, I. Anžel, A.C. Kneissl, A. Križman, E. Unterweger, B. Kosec, M. Bizjak, Microstructure of rapidly solidified Cu-AlNi shape memory alloy ribbons, J. Mater. Process. Technol. 162-163 (2005) 220-229, doi: https://doi.org/10.1016/j. jmatprotec.2005.02.196.

5. W. Huang, On selection of shape memory alloys for actuators, Mater. Design 23 (2002) 11-19, doi: https://doi. org/10.1016/S0261-3069(01)00039-5.

6. S. Zeghdane, K. Necib, A. Britah, Structural characterization of $\mathrm{Cu}-13.58 \% \mathrm{Al}-3.94 \% \mathrm{Ni}$ (wt.\%) shape memory alloy elaborated by fusion, EPJ Web of Conferences, 6, 2010, p. 29001 1, https://doi.org/10.1051/epjconf/20100629001.

7. R. Kainuma, S. Takahashi, K. Ishida, Thermoelastic Martensite and Shape Memory Effect in Ductile Cu-Al-Mn Alloys, MetalL. Mater. Trans. A 27A (1996) 2187-2195, doi: https:// doi.org/10.1007/BF02651873.

8. M. R. Rezvani, A. Shokuhfar, Synthesis and characterization of nano structured Cu-Al-Mn shape memory alloy by mechanical alloying, Mater. Sci. Eng. A 532 (2012) 282-286, doi: https://doi.org/10.1016/j.msea.2011.10.093.

9. U. S. Mallik, V. Sampath, Influence of quaternary alloying additions on transformation temperatures and shape memory properties of $\mathrm{Cu}-\mathrm{Al}-\mathrm{Mn}$ shape memory alloy, J. Alloys Comp. 469 (2009) 156-163, doi: https://doi.org/10.1016/j. jallcom.2008.01.128.

10. J. Chen, Z. Li, Y. Y. Zhao, A high-working-temperature CuAIMnZr shape memory alloy, J. Alloys Comp. 480 (2009) 481484, doi: https://doi.org/10.1016/j.jallcom.2009.01.104.

11. G. Lojen, A. C. Kneissl, M. Gojić, R. Rebeka, M. Čolić, I. Anžel, Continuous Casting of Cu-Al-Ni Shape Memory Alloys, Livarski vestnik 57 (2010) 172-193.

12. M. Gojić, L. Vrsalović, S. Kožuh, A. C. Kneissl, I. Anžel, S. Gudić, B. Kosec, M. Kliškić, Electrochemical and microstructural study of Cu-Al-Ni shape memory alloy, J. Alloys Comp. 509 (2011) 9782-9790, doi: https://doi.org/10.1016/j.jall- 
com.2011.07.107

13. Y. Q. Jiao, Y. H. Wen, N. Li, J. Q. He, J. Teng, Effect of solution treatment on damping capacity and shape memory effect of a CuAIMn alloy, J. Alloys Comp. 491 (2010) 627-630, doi: https://doi.org/10.1016/j.jallcom.2009.11.026.

14. A. Mielczarek, W. Riehemann, S. Vogelgesang, B. Tonn, Mechanical and Fatigue Properties of Cu-Al-Mn shape memory alloys with influence of mechanical cycling on amplitude dependence of internal friction at room temperature, Solid State Phenomena 137 (2008) 145-154, doi: https://doi. org/10.4028/www.scientific.net/SSP.137.145.

15. Y. Sotou, T. Omari, N. Koeda, R. Kainuma, K. Ishida, Effect of grain size and texture on damping properties of Cu-Al-Mn-based shape memory alloys, Mater. Sci. Eng. A 438-440 (2006) 743-746, doi: https://doi.org/10.1016/j. msea.2006.02.085.

16. Z. Wang, X. F. Liu, J. X. Xie, Effect of $\gamma_{2}$ phase evolution on mechanical properties of continuous columnar-grained Cu-Al-Ni alloy, Mat. Sci. Eng. A 532 (2012) 536-542, doi: https://doi.org/10.1016/j.msea.2011.11.019.

17. Y. Sutou, T. Omori, A. Furukawa, Y. Takahaski, R. Kainuma, K.
Yamaucki, S. Yamashita, K. Ishida, Development of medical guide wire of $\mathrm{Cu}-\mathrm{Al}-\mathrm{Mn}$-base superelastic alloy with functionally graded characteristics, J. Biomed. Mat. Res. 69B (2004) 64-69, doi: https://doi.org/10.1002/jbm.b.10079.

18. R. Kainuma, N. Satoh, X. J. Liu, I. Ohnuma, K. Ishida, Phase equilibria and Heusler phase stability in the Cu-rich portion of the Cu-Al-Mn system, J. Alloys Comp. 266 (1998) 191200, doi: https://doi.org/10.1016/S0925-8388(97)00425-8.

19. Z. Y. Pan, Z. Li, M. P. Wang, C. P. Deng, S. H. Li, F. Zheng, The effect of non-isothermal aging on the $\beta$ phase of $\mathrm{Cu}_{73} \mathrm{Al}_{24} \mathrm{Mn}_{3}$ alloy, Mat. Sci. Eng. A 467 (2007) 104-107, doi: https://doi. org/10.1016/j.msea.2007.02.123.

20. S. Stanciu, L. G. Bujoreanu, I. Ionita, A. V. Sandu, A. Enacke, A structural-morphological study of a $\mathrm{Cu}_{63} \mathrm{Al}_{26} \mathrm{Mn}_{11}$ shape memory alloy, Proc. Spie 7297, Advanced Topics in Optoelectronics, Microelectronics and Nanotechnologies IV, 72970C (January 06, 2009), doi: https://doi.org/10.1117/12.823621.

21. Y. Sutou, T. Omori, R. Kainuma, N. Ono, K. Ishida, Enhancement of superelasticity in $\mathrm{Cu}-\mathrm{Al}-\mathrm{Mn}-\mathrm{Ni}$ shape-memory alloys by texture control, Metall. Mater. Trans. A 33 (2002) $2817-$ 2824, doi: https://doi.org/10.1007/s11661-002-0267-2.

\title{
SAŽETAK
}

\author{
Utjecaj toplinske obrade na mikrostrukturu i mehanička svojstva legure \\ Cu-Al-Mn s prisjetljivosti oblika \\ Stjepan Kožuh, ${ }^{a^{*}}$ Mirko Gojić, a Ivana Ivanić, ${ }^{a}$ Tamara Holjevac Grgurić, \\ Borut Kosec ${ }^{\mathrm{b}}$ i Ivan Anželc
}

Šipke promjera $8 \mathrm{~mm}$ proizvedene su iz legure Cu-Al-Mn s prisjetljivosti oblika tehnikom kontinuiranog lijevanja. Uzorci su karakterizirani pomoću optičke mikroskopije i pretražne elektronske mikroskopije uz analizu EDX. Kontinuirano lijevana legura je pokazala mjestimičnu prisutnost martenzitne faze, dok je nakon kaljenja nastala potpuno martenzitna mikrostruktura. Kaljenje uzoraka utjecalo je na mehanička svojstva i na promjenu morfologije prijeloma. Nakon starenja pri $200{ }^{\circ} \mathrm{C}$ i $300{ }^{\circ} \mathrm{C}$ porasla je vlačna čvrstoća a izduženje se drastično smanjilo. Morfologija prijelomne površine se mijenjala od duktilne do mješavine interkristalne i duktilne.

\footnotetext{
Ključne riječi

Legure s prisjetljivosti oblika (SMAs), mehanička svojstva, mikrostruktura, pretražna elektronska mikroskopija (SEM), kaljenje, starenje
}

a Sveučilište u Zagrebu Metalurški fakultet, Aleja narodnih heroja 3, 44103 Sisak, Hrvatska

b Sveučilište u Ljubljani, Prirodoslovnotehnički fakultet, Aškerčeva 12, 1000, Ljubljana,

Slovenija

'Sveučilište u Mariboru, Strojarski fakultet, Smetanova 17, 2000, Maribor, Slovenija
Izvorni znanstveni rad Prispjelo 20. lipnja 2017. Prihvaćeno 25. rujna 2017. 